\title{
Wpływ stopnia ryzyka na wysokość cen transferowych w przypadku pożyczek między podmiotami powiązanymi
}

\author{
Radosław Witczak* \\ Artur Zimny** iD
}

\section{Wstęp}

Do kluczowych problemów znajdujących się na agendzie międzynarodowej, ale także krajowej, należy problematyka ucieczek przed podatkami. Jednym z instrumentów, jakie mogą wykorzystywać podmioty gospodarcze do obniżania ciężarów podatkowych, są ceny transferowe. Określają one wartość dóbr i usług sprzedawanych powiązanym przedsiębiorstwom. Cen transferowych nie stworzono z myślą o zmniejszaniu należności podatkowych, jednakże ich odpowiednie kształtowanie może prowadzić do redukcji podatku, dlatego zarówno na poziomie międzynarodowym, jak i krajowym, opracowywane są regulacje mające na celu przeciwdziałanie wykorzystywaniu cen transferowych do ucieczek przed podatkami. Szczególnym przypadkiem transakcji podlegających tym przepisom są transakcje pożyczek (kredytów). Celem artykułu jest ocena wpływu stopnia ryzyka ponoszonego przez pożyczkodawcę na cenę udzielanej pożyczki przy ustalaniu ceny transferowej w przypadku pożyczek między podmiotami powiązanymi. W pracy przyjęto następującą hipotezę: stopień ryzyka ponoszonego przez pożyczkodawcę jest istotnym czynnikiem wpływającym na cenę udzielanej pożyczki i powinien być uwzględniany przy ustalaniu ceny transferowej w przypadku pożyczek między podmiotami powiązanymi.

\footnotetext{
* Radosław Witczak - dr, Instytut Ekspertyz Ekonomicznych i Finansowych w Łodzi; Uniwersytet Łódzki, Wydział Ekonomiczno-Socjologiczny, Katedra Bankowości Centralnej i Pośrednictwa Finansowego, ORCID: 0000-0002-9746-0016, radoslaw.witczak@uni.lodz.pl

** Artur Zimny - dr, Uniwersytet Łódzki, Wydział Ekonomiczno-Socjologiczny, Katedra Finansów i Rachunkowości MSP, ORCID: 0000-0002-6658-952X, artur.zimny@uni.lodz.pl
} 


\section{Istota i specyfika cen transferowych}

Istotnym problemem związanym z ucieczkami przed podatkami są ceny transferowe. Określają one wartość dóbr i usług sprzedawanych powiązanym przedsiębiorstwom w obrębie holdingu, koncernu lub grupy kapitałowej (Jaeger 1987, s. 29-30; O'Shaughnessy 2003, s. 5). Ceny transferowe nie zostały stworzone w celu zmniejszania należności podatkowych, mogą w przedsiębiorstwach pełnić różne funkcje. Jednak ich odpowiednie kształtowanie może prowadzić między innymi do redukcji kwot podatku dochodowego. Nastąpić może przerzucanie dochodu do korzystniej opodatkowanego, powiązanego przedsiębiorstwa. Działanie to może polegać na sprzedaży towarów lub usług po zaniżonych cenach lub zakupu towarów czy usług po zawyżonych cenach. W efekcie takich działań zmniejszają się przychody lub zwiększają koszty wykazywane przez przedsiębiorstwa, co prowadzi do obniżania podstawy opodatkowania. Ich skutkiem jest więc również uszczuplenie dochodów budżetów wielu państw (Jankowski 2019, s. 235236). Dlatego prace mające przeciwdziałać wykorzystywaniu cen transferowych do redukcji podatku prowadzone są m.in. na poziome międzynarodowym, Unii Europejskiej, OECD, jak również na poziome krajowym (Kolanowski, Winiarski 2018, s. 21-22; Mariański i in. 2018, s. 9-13; Stamblewska-Urbaniak, Zbroiński 2019, s. 41-50; EU 2005).

Istotne działania zmierzające do przeciwdziałania przerzucaniu dochodów w skali międzynarodowej za pomocą cen transferowych podjęła OECD. Ich efektem była publikacja raportów i sprawozdań dotyczących tego zagadnienia. Miały one na celu m.in. przyjęcie przez członków OECD wspólnych standardów postępowania w przypadku stosowania cen transferowych. Szczególne znaczenie w wytycznych OECD ma zasada „długości ramienia” (arm s length), nazywana również „zasadą cen rynkowych” (Georgijew, Sadowski 2003), kierowana do przedsiębiorstw i administracji skarbowej, a dotycząca ustalania cen transferowych na poziomie rynkowym.

Również na poziomie krajowym problematyka cen transferowych została uregulowana w przepisach dotyczących podatków dochodowych, przy czym na przestrzeni lat ulegały one częstym zmianom. Do końca roku 2018 adresatem przepisów były organy podatkowe - obowiązywała reguła pozwalająca organom podatkowym na korektę (w drodze szacowania) cen ustalanych przez podatników. Regulacje nie ingerowały wprost $\mathrm{w}$ warunki ustalania cen pomiędzy podmiotami powiązanymi. Natomiast od roku 2019 przepisy wprost nakazują przedsiębiorcom dla celów podatkowych ustalanie na bieżąco (tj. w momencie realizacji transakcji) cen transferowych na warunkach, jakie ustaliłyby podmioty niezależne. Oczywiście organy podatkowe mogą dokonać korekty cen transferowych, jeśli podatnik nie zastosował warunków rynkowych. W literaturze przedmiotu wskazuje się, że jest to bardzo istotna zmiana w podejściu do problematyki cen transferowych 
(Laskowska 2019, s. 29-33). Praktyczny efekt regulacji obowiązujących do 2018 r., jak i od 2019 r., jest jednak niezmieniony. Podatnicy pragnący uniknąć sporów $\mathrm{z}$ organami administracji skarbowej $\mathrm{w}$ przypadku stosowania cen transferowych powinni ustalać je na poziomie rynkowym.

Wskazuje się, że jeśli podmioty powiązane ustaliły między sobą warunki umowy pożyczki, naliczając bardzo małe odsetki, choćby w wysokości 1 zł (niezależenie od wartości i czasu trwania tej pożyczki), to organ administracji skarbowej będzie musiał wykazać, że warunki te różnią się od warunków, jakie ustaliłyby podmioty niezależne. Jeżeli organy podatkowe udowodnią, że warunki ustalone przez podmioty powiązane różnią się od tych stosowanych przez podmioty niezależne, to dokonają wymiaru podatku w oparciu o to, jak zachowałyby się podmioty niezależne. Wymierzając podatek pominą więc te elementy stanu faktycznego, które różnią się od tego, jak zachowałyby się podmioty niezależne, a dokonają wymiaru podatku w oparciu o to, jak zachowałyby się podmioty niezależne i obliczą dochód potencjalny, zmieniając np. wysokość ustalonych odsetek przyjmowanych do wyznaczenia podstawy opodatkowania (Gajewski 2019).

Zarówno przepisy obowiązujące do 31 grudnia 2018 r. (art. 11 ustawy o podatku dochodowym od osób prawnych oraz art. 25 ustawy o podatku dochodowym od osób fizycznych w ich ówczesnym brzmieniu), jak i od 2019 r. (rozdział 1a ustawy o podatku dochodowym od osób prawnych oraz rozdział $4 \mathrm{~b}$ ustawy o podatku dochodowym od osób fizycznych w ich znowelizowanym brzmieniu) poruszają (czasem w odmienny sposób) liczne kwestie związane z problematyką cen transferowych. Regulacje określają m.in. podmioty uznawane za powiązane, metody szacowania dochodu (ustalania ceny transferowej) oraz warunki zastosowania metod szacowania dochodu. Dodatkowo na podmioty gospodarcze nałożono obowiązki dokumentacyjne, których celem jest pomoc w ustaleniu, czy cena transferowa faktycznie nie odbiega od warunków rynkowych (Piekarz 2018; Laskowska 2019, s. 29-33).

\section{Warunki pożyczki między podmiotami powiązanymi jako szczególny rodzaj ceny transferowej}

Szczególnym rodzajem transakcji, jaką mogą między sobą zawrzeć podmioty powiązane, jest udzielenie pożyczki. W zamian za udostępnienie środków jeden $z$ tych podmiotów powinien ponieść odpowiednie opłaty na rzecz drugiego. Ceną pożyczki jest zwykle (i przede wszystkim) jej oprocentowanie, możliwe są jednak opłaty dodatkowe, jak w przypadku udzielania kredytów przez banki, które stosują np. prowizje czy opłaty manipulacyjne. Suma odsetek i innych opłat stanowi 
w takim przypadku cenę transferową, która - zgodnie z wymienionymi wcześniej przepisami - powinna odpowiadać cenie rynkowej.

Przepisy ustawowe (poza pewnym wyjątkiem określanym jako safe harbour i omówionym poniżej) nie odwołują się wprost do zasad wyceny pożyczek. Większość licznych zmian, jakich dokonano w regulacjach ustawowych dotyczących cen transferowych, nie odnosiła się bezpośrednio do kwestii związanych $\mathrm{z}$ udzielaniem pożyczek. W związku z tym badając rynkowość umów pożyczek należy stosować reguły ogólne wynikające z rozwiązań ustawowych. Wspomnianym wyjątkiem jest wprowadzony do polskich przepisów szczególny instrument, stosowany w wielu innych krajach, zwany safe harbour („,bezpieczna przystań”). Istota tego rozwiązania polega na tym, że jeśli spełnione są warunki określone w przepisach, to podatnicy mogą zastosować uproszczenia w ustalaniu ceny, która będzie uznana za rynkową. Wspomniane warunki dotyczą m.in. składników ceny pożyczki, jej okresu, wartości wzajemnych zobowiązań podmiotów powiązanych z tytułu pożyczek oraz miejsca zamieszkania, siedziby lub zarządu pożyczkodawcy. Jeśli warunki są spełnione, można zastosować oprocentowanie wskazane wprost $\mathrm{w}$ obwieszczeniu ministra właściwego do spraw finansów publicznych. Pozwala to na uznanie przyjętej ceny za rynkową, a tym samym - odstąpienie przez organ od określenia dochodu (straty) podatnika w zakresie wysokości jego wynagrodzenia (Krzyżaniak, Hornowska 2020). Należy zgodzić się z tezą, że zastosowanie oprocentowania wynikającego z safe harbour nie powoduje, że umowa staje się rynkowa (Klimek 2019).

Natomiast istotne zmiany związane z pożyczkami pojawiły się w rozporządzeniach ministra finansów dotyczących cen transferowych. Przepisy zawarte w rozporządzeniach uchwalonych już w październiku $1997 \mathrm{r}$. i obowiązujących do 31.12.2018 r. niezależnie od zmian samych rozporządzeń wskazywały wprost istotne cechy transakcji pożyczki, które powinny być uwzględniane przy określaniu jej ceny, aby odpowiadała ona cenie rynkowej. Regulacje wskazywały, że wartość rynkową odsetek w przypadku udzielenia pożyczki podmiotowi powiązanemu określa się na podstawie wysokości najniższych odsetek, jakie dany podmiot musiałby zapłacić podmiotowi niezależnemu za uzyskanie kredytu (pożyczki) na podobny okres w porównywalnych warunkach (§ 15 ust. 2 Rozporządzenia Ministra Finansów, 1997).

Co więcej, normy prawne określały, że powinny zostać przy tym uwzględnione wszystkie istotne okoliczności związane z konkretnym przypadkiem, a w szczególności (§ 15 ust. 3 Rozporządzenia Ministra Finansów, 1997):

1) kwota pożyczki (kredytu) oraz okres, na jaki została udzielona;

2) charakter i cel pożyczki (kredytu);

3) ryzyko i zabezpieczenie pożyczki (kredytu), z uwzględnieniem specjalnych warunków, jakie pożyczkodawca (kredytodawca) mógłby przyznać pożyczkobiorcy (kredytobiorcy) niezależnemu; 
4) waluta pożyczki (kredytu), ryzyko zmian kursów walut, kosztów środków zabezpieczających pożyczkę (kredyt) oraz środków ograniczających ryzyko zmiany kursów walut;

5) wysokość prowizji.

Identyczną treść przepisu zawierały kolejne rozporządzenia, wydane we wrześniu 2009 r. i obowiązujące do 31.12.2018 r., zmienił się jedynie numer jednostki redakcyjnej, w której zawarto ten przepis ( $\$ 21$ ust. 2, 3 Rozporządzenia Ministra Finansów, 2009a; § 21 ust. 2, 3 Rozporządzenia Ministra Finansów, 2009b).

Normy zawarte $\mathrm{w}$ rozporządzeniach wskazywały różne czynniki, które należało uwzględnić przy sprawdzaniu czy dana transakcja ma rynkowy charakter, np. wartość pożyczki, okres jej udzielenia, cel pożyczki itp. Przy ocenie porównywalności należało uwzględniać każdy z tych elementów (Mika 2017, s. 204-205), ale także inne czynniki wpływające na sytuację panującą na rynkach finansowych, np. wysokość inflacji, stóp procentowych (Dmowski 2006, s. 81).

Należy zwrócić uwagę, że kwestia stopnia ryzyka ponoszonego przez pożyczkodawcę pojawia się $\mathrm{w}$ czterech z pięciu wymienionych w przepisie okoliczności. Jako pierwszą okoliczność wskazano kwotę pożyczki (a im większa kwota, tym większa ekspozycja na ryzyko problemów z płynnością w razie nieotrzymania zwrotu pożyczki w terminie) oraz okres, na jaki zaciągnięto pożyczkę (a im dłuższy okres, tym większa niepewność co do przyszłych okoliczności jej spłaty, czyli większe ryzyko niezwrócenia środków). Druga okoliczność to charakter i cel pożyczki, co również pośrednio wpływa na stopień ryzyka - w przypadku finansowania pożyczką atrakcyjnej nieruchomości czy wysoce płynnych zapasów surowców jest ono nieporównanie mniejsze niż w przypadku inwestowania ich w innowacyjny, niezweryfikowany rynkowo projekt. W okoliczności trzeciej ryzyko wymienione jest wprost, jak również możliwości redukowania go poprzez zastosowanie zabezpieczeń lub specjalnych warunków. W okoliczności czwartej przywołano przede wszystkim ryzyko związane ze zmiennością kursów walut. Jedynie piąta okoliczność nie wiąże się $\mathrm{z}$ ryzykiem, bowiem stanowi de facto składnik ceny, która ma być określana.

Od roku 2019 obowiązują nowe rozporządzenia: Rozporządzenie Ministra Finansów w sprawie cen transferowych $\mathrm{w}$ zakresie podatku dochodowego od osób prawnych z dnia 21 grudnia 2018 r. (Dz.U. z 2018 r. poz. 2491 ze zm.) oraz Rozporządzenie Ministra Finansów w sprawie cen transferowych w zakresie podatku dochodowego od osób fizycznych z dnia 21 grudnia 2018 r. (Dz.U. z 2018 r. poz. 2502 ze zm.). W rozporządzeniach tych nie ma przepisu, który odnosiłby się do pożyczek. Oznacza to, że do wycen transakcji finansowych, w tym pożyczek, stosuje się przepisy ogólne. Zarazem występuje w literaturze pogląd, że analizując rynkowość transakcji pożyczek, nadal można uwzględniać czynniki wskazane w przepisach obowiązujących do 2018 r. (Kosieradzki i in. 2019). 
Oceniając wpływ stopnia ryzyka ponoszonego przez pożyczkodawcę na cenę udzielanej pożyczki przy szacowaniu ceny transferowej, oprócz regulacji ustawowych, należy uwzględnić również wytyczne OECD oraz krytyczną analizę literatury przedmiotu. Generalnie wytyczne OECD obowiązujące do $2020 \mathrm{r}$. nie określały w sposób szczegółowy zasad dokonywania wycen udzielanych pożyczek (poza pewnymi wyjątkami). Oznacza to, że zastosowanie miały ogólne zasady ustalone w wytycznych OECD. Jeden z punktów wytycznych wprost stwierdza, że podmiot finansujący może oczekiwać zwrotu przekazanych środków z uwzględnieniem ryzyka. Przy ustalaniu zwrotu środków finansowych ważne jest, aby rozważyć opcje finansowania realistycznie dostępne dla strony otrzymującej środki (OECD 2017, p. 6.62). Pozostałe wskazówki zawarte w wytycznych OECD, a dotyczące pożyczek, nie są istotne dla celów niniejszego artykułu. Zatem ogólne reguły określone w wytycznych OECD w zakresie ustalania rynkowości cen transferowych jak najbardziej mają zastosowanie w przypadku wyceny pożyczek (OECD 2017). Co więcej, OECD, zdając sobie sprawę ze specyfiki transakcji finansowych, pracowało nad wytycznymi w tym zakresie (Kosieradzki $i$ in. 2019). W 2020 r. opublikowano wytyczne w zakresie transakcji finansowych (OECD 2020), jednak ze względu na fakt, że dokumentacja podatkowa przedstawiona w artykule dotyczyła okresu wcześniejszego niż rok 2020, wytyczne te nie miały wpływu na jej sporządzenie.

Natomiast w literaturze przedmiotu problematyka wycen pożyczek i uwzględniania ryzyka na potrzeby ustalania rynkowości cen transferowych jest traktowana w sposób bardzo zróżnicowany. Jak pokazują przeprowadzone badania, w praktyce do wycen pożyczek najczęściej stosuje się metodę porównywalnej ceny niekontrolowanej, chociaż wykorzystuje się też metodę koszt plus, a także inne metody, zarówno wymienione, jak i niewymienione w regulacjach (Baćkowski 2001, s. 18; Felis 2008, s. 34). W niektórych pozycjach literaturowych kwestia wycen pożyczek i uwzględniania ryzyka nie jest traktowana bardzo szczegółowo. Jako podstawową metodę ustalania odsetek rynkowych zaleca się stosownie porównywalnej ceny niekontrolowanej, przyjmując, że taką porównywalną transakcję na rynku można zidentyfikować (Wyciślok 2014, s. 344, 466-467; Ścierska 2016). Oczywiście należy się zgodzić z tym, że zastosowanie porównywalnej ceny niekontrolowanej jest jak najbardziej zasadne, dlatego teoretycznie najlepszym rozwiązaniem byłoby sięgnięcie do identycznej lub podobnej umowy pożyczki zawartej przez niezależne podmioty. Kaniewska-Środecka (2018, s. 245) stwierdza, że w praktyce organy podatkowe kwestionują oprocentowanie pożyczek na bazie własnej analizy danych pozyskiwanych w bankach, przy czym zwraca uwagę na to, że kredyty bankowe nie są wprost porównywalne z pożyczkami. Należałoby również sięgnąć do pożyczek udzielanych przez sektor pozabankowy. Dlatego wyrażany jest pogląd, że w pierwszej kolejności należy sprawdzić, czy na rynku funkcjonują podmioty, które mogłyby udzielić podatnikowi pożyczki 
na cel, na który zawierana jest przedmiotowa pożyczka. Dopiero gdy okaże się, że takie firmy nie istnieją, można sięgnąć do praktyki obowiązującej w sektorze bankowym (Nykiel, Strzelec 2014).

Informacje, do jakich mają dostęp podatnicy, są ograniczone, więc ustalenie warunków pożyczek zawieranych na rynku jest bardzo utrudnione. Należy zgodzić się z tezą, że w pierwszej kolejności powinno się szukać firm pożyczkowych, a jeśli dostęp do takich informacji nie jest możliwy, wówczas konieczne jest sięgnięcie do informacji z sektora bankowego. W praktyce mogą jednak wystąpić trudności z identyfikowaniem porównywalnych transakcji, ponieważ umowy pożyczki czy kredytu z reguły są objęte tajemnicą handlową lub bankową. W efekcie ustalenie bazy porównawczej może być bardzo trudne. Problematyczność ustalania wartości rynkowej pożyczek podkreśla np. Sulik-Górecka (2009, s. 267).

$\mathrm{W}$ literaturze można spotkać się z różnymi podejściami do rozwiązania problemu wyceny odsetek od pożyczek w przypadku braku dostępu do porównywalnych pożyczek czy też kredytów w różnych sytuacjach. Za dane porównawcze w pierwszej kolejności powinny posłużyć dane wewnętrzne spółki pozyskującej pożyczkę. Jeśli brakuje takich danych, należy sięgnąć do ofert banków komercyjnych, z zastrzeżeniem, że powinny dotyczyć produktów finansowych o podobnym charakterze. W dalszej kolejności można skorzystać z danych NBP dotyczących średniego oprocentowania produktów o charakterze zbliżonym do udzielanej pożyczki (Wiśniewski, Kromer 2015, s. 238, 245-247).

W literaturze przedmiotu zwraca się również uwagę na uwzględnienie ryzyka jako jednego z najistotniejszych elementów wyceny pożyczek. Kosieradzki $\mathrm{i}$ in. (2019) proponują różne sposoby postępowania w tym zakresie. Jednym z rozwiązań jest ocena płynności finansowej pożyczkobiorcy i jego wypłacalności. Taka analiza powinna być pomocna w ustalaniu oprocentowania. Powinno ono wynosić:

$$
1+\mathrm{R}+\mathrm{RP}=(1-\mathrm{PD}) \times(1+\mathrm{r})+\mathrm{PD} \times(1-\mathrm{LGD}) \times(1+\mathrm{r})
$$

gdzie:

$\mathrm{R}$ - stopa bazowa,

RP - premia za ryzyko, czyli spread (narzut) na stopie bazowej,

PD - prawdopodobieństwo niewypłacalności,

$\mathrm{r}$ - rynkowa stopa procentowa,

LGD - strata w przypadku niewypłacalności (dotyczy tej części długu, który nie może być odzyskany).

Stopa bazowa to stopa procentowa (zwrot) na inwestycji wolnej od ryzyka. Dobrym benchmarkiem dla tej stopy jest oprocentowanie lokat bankowych lub bonów skarbowych. Spread natomiast jest wynagrodzeniem za ryzyko i jest 
proporcjonalny do zdolności kredytowych danego podmiotu (ryzyka niewypłacalności). Sposobem badania tego ryzyka są oceny agencji ratingowych. Jednakże, jak zauważają autorzy, ratingi są przyznawane jedynie spółkom globalnym (Kosieradzki i in. 2019), dlatego jako inne podejście proponują oni sprawdzenie ryzyka niewypłacalności poprzez przeprowadzenie tzw. analizy Altman's Z-Score, z wykorzystaniem modelu Altmana dla rynków rozwijających się w postaci:

$$
\text { Wskaźnik } \mathrm{Z}=6,56 \mathrm{X}_{1}+3,26 \mathrm{X}_{2}+6,72 \mathrm{X}_{3}+1,05 \mathrm{X}_{4}+3,25
$$

gdzie:

$\mathrm{X}_{1}$ - kapitał pracujący (obrotowy)/aktywa,

$\mathrm{X}_{2}$ - zysk zatrzymany/aktywa,

$\mathrm{X}_{3}-$ EBIT/aktywa,

$\mathrm{X}_{4}$ - kapitały/zobowiązania.

Następnie wskaźnik Z jest przeliczany na ocenę ratingową, taką, jakie nadają instytucje ratingowe. Znając tak ustalony rating pożyczkobiorcy, znajduje się podmioty o takim samym ratingu, a poziom odsetek rynkowych ustala się na podstawie finansowania dłużnego, $\mathrm{z}$ którego korzystają wyszukane w ten sposób podmioty. Podstawą do wyszukania takich danych (podmiotów i transakcji) są bazy danych takie jak LoanConnector. Możliwe jest również ustalanie oprocentowania z wykorzystaniem danych pochodzących z polskiego rynku obligacji Catalyst. Po wyznaczeniu oceny ratingowej, zgodnie z powyższą procedurą, należy znaleźć podmioty o takim samym ratingu, których obligacje są notowane na rynku Catalyst. Oprocentowania tych obligacji wyznaczają rynkowy zakres ceny pożyczki (Kosieradzki i in. 2019).

Inne podejście do ceny rynkowej dla pożyczki otrzymanej przez firmę polską od powiązanej firmy z Niemiec proponuje Menet (2011, s. 136-141). W przedstawionej przez tego autora analizie dla celów porównawczych skorzystano z danych zebranych w bazie LoanConnector. Uwzględniono 15 pożyczek w krajach regionu (np. Rosji, Turcji, Macedonii itd.), przy czym pożyczkobiorcami były banki, co stawia pod znakiem zapytania porównywalność takich transakcji. Z powodu braku informacji dotyczących części wyselekcjonowanych pożyczek do analizy porównawczej nie wprowadzono kryterium wysokości prowizji - budzi to kolejne wątpliwości co do tego, czy ustalony w ten sposób zakres cen rzeczywiście odpowiada cenom rynkowym, jako że prowizja jest istotnym elementem ceny pożyczki. Należy natomiast podkreślić, że autor zwrócił uwagę, iż niższe ryzyko ponoszone przez pożyczkobiorcę może być podstawą do zaakceptowania przez niego wyższej ceny pożyczki (Menet 2011, s. 134), co w konsekwencji oznacza, że wyższe ryzyko uprawnia pożyczkodawcę do zażądania wyższej ceny. Ryzyko zostało również pośrednio uwzględnione w przedstawionym przez Meneta 
badaniu - wybór transakcji do analizy porównawczej zawężono do regionu, do którego należy Polska, oraz do pożyczek z zabezpieczeniem, ponieważ analizowana pożyczka również była zabezpieczona (Menet 2011, s. 137).

Przedstawiony przegląd literatury pokazuje, że w celu ustalenia rynkowości pożyczki zawieranej przez podmioty powiązane chętnie wskazywanym źródłem są transakcje zawierane przez banki (kredyty, pożyczki), wyspecjalizowane firmy pożyczkowe (pożyczki) lub rynek korporacyjnego długu notowanego (np. obligacje).

$\mathrm{Z}$ przeglądu literatury wynika także, że dominującą metodą ustalania rynkowej ceny pożyczki jest metoda porównywalnej ceny niekontrolowanej. Możliwe jest jednak również inne podejście, w ramach którego proponuje się zastosowanie metody koszt plus. Podejście to dotyczy przypadków, w których pożyczkodawca udziela pożyczki z własnego majątku. Proponuje się wówczas uznanie, że pożyczkodawca działa jako centrum zysków bądź centrum inwestycji, podejmując decyzję dotyczącą lokowania kapitału. Decyzja o inwestycji z punktu widzenia pożyczkodawcy za każdym razem powinna być poprzedzona odpowiednią analizą opłacalności inwestycji i - nade wszystko - analizą ryzyka. Proponuje się wówczas skorzystanie z metody koszt plus. Natomiast źródłem danych powinna być baza sprawozdań finansowych (Kosieradzki i in. 2019).

$\mathrm{Z}$ dokonanego przeglądu literatury wynika, że zdaniem części autorów stopień ryzyka istotnie wpływa na cenę pieniądza w przypadku udzielania finansowania dłużnego i jako taki powinien być również uwzględniany w określaniu ceny transferowej, jaką jest odpłatność za pożyczkę udzieloną przez podmiot powiązany. Dla poprawnego określenia ceny kapitału dłużnego istotna jest też konstrukcja tej ceny, na którą składać się mogą różne elementy, komplikując porównywalność. Zagadnienie to omówiono w kolejnej części pracy.

\section{Cena kapitału dłużnego i jej porównywalność}

W długim okresie, ze względu na zmieniające się warunki rynkowe, ceny kapitałów udzielanych jako dłużne nie są stałe. Jednym z najczęściej wykorzystywanych parametrów odzwierciedlających zmiany cen pieniądza jest Wibor, tj. oprocentowanie, na jakie banki są gotowe pożyczać pieniądze między sobą na rynku międzybankowym. Wiele kredytów dla przedsiębiorstw ma ustalone oprocentowanie zmienne, oparte o Wibor (np. Wibor 1M, Wibor 3M). W konkretnych umowach oprocentowanie ustalane jest jako Wibor (,hurtowa” cena pieniądza na rynku) powiększony o marżę, która dla banku jest nadwyżką ponad tę „hurtową” cenę i stanowi dla niego rekompensatę ponoszonego ryzyka kredytowego. W przypadku kredytów o oprocentowaniu stałym Wibor nie jest wprost wymieniony jako składnik ceny finansowania, jednak nie ulega wątpliwości, że oferując stawkę 
oprocentowania, bank kalkuluje ją z uwzględnieniem aktualnych hurtowych cen pieniądza i przewidywań co do ich zmienności w przyszłości.

Oprócz samego oprocentowania (odsetek) banki pobierają zwykle dodatkowe opłaty, które zwiększają łączny koszt kredytu, np. prowizje przygotowawcze, prowizje administracyjne, prowizje za przedłużenie, tzw. prowizje za gotowość itd. Prowizje, których poniesienie jest konieczne dla uzyskania kredytu (lub dalszego korzystania z niego), powinny być uwzględniane przy kalkulowaniu ceny kredytu, ponieważ mogą stanowić znaczną część kosztów ponoszonych przez kredytobiorcę i być de facto ukrytym oprocentowaniem. Aby ustalić rzeczywistą cenę kredytu, należy więc uwzględnić kwotę pozyskanego kapitału oraz wszystkie kwoty, jakie kredytobiorca ma z tytułu jego pozyskania zapłacić kredytodawcy (spłata kapitału i odsetek, a także prowizji czy innych opłat), oraz momenty czasowe, w których te płatności mają nastąpić. Rozłożenie poszczególnych przepływów pieniężnych w różnych momentach czasowych powoduje, że określenia łącznej ceny nie można sprowadzać do zwykłego zsumowania kwoty kosztów i odniesienia jej do kwoty kapitału. Konieczne jest uwzględnienie formuł kalkulacji wartości pieniądza w czasie, pozwalających wyznaczyć stopę procentową, którą przyjęło się wyrażać w ujęciu rocznym. Tak wyznaczone oprocentowanie jest rzeczywistą roczną stopą oprocentowania (RRSO), której metodę obliczania opisano w Ustawie o kredycie konsumenckim (2011). Mimo że ustawa ta dotyczy jedynie kredytów udzielanych konsumentom (czyli osobom fizycznym na cele inne niż działalność gospodarcza), to przedstawiona w niej metoda wyznaczania RRSO (oparta na koncepcji IRR, tj. wewnętrznej stopy zwrotu) jest uniwersalna i właściwa dla wszelkich form odpłatnego udzielania kapitału o ustalonych harmonogramach spłat, tj. kredytów, pożyczek, faktoringu, leasingu, obligacji itd. RRSO to syntetyczna, czytelna i zrozumiała miara kosztu kapitału dłużnego, sprowadzająca do porównywalności transakcje o bardzo różnej strukturze wynikających z nich przepływów (NBP 2015, s. 46-55).

Należy zauważyć, że w ramach transakcji kredytowej bank może żądać zawarcia dodatkowych umów, generujących dodatkowe opłaty na rzecz banku lub powiązanego $\mathrm{z}$ nim podmiotu, np. za prowadzenie rachunku bankowego czy różnego rodzaju ubezpieczenia. Kwestia ujmowania tych kosztów w wyliczaniu RRSO jest dyskusyjna. Z jednej strony ich poniesienie warunkuje uzyskanie kredytu, są to więc koszty, których nie można uniknąć, co przemawia za wliczaniem ich do RRSO. Z drugiej strony jednak, są to opłaty ponoszone nie za samo finansowanie, tylko za usługi dodatkowe, co sugeruje, że nie powinny być one wliczane w RRSO, która jest de facto, ceną samego finansowania. W przypadku większej liczby ofert porównywalność może być zaburzona, np. jeden bank może żądać wykupienia ubezpieczenia od podmiotu, który sam wskaże, drugi - od dowolnego podmiotu, a trzeci może w ogóle nie wymagać ubezpieczenia. 
Ponadto parametry cenowe tych dodatkowych usług, wykraczających poza ramy zasadniczej umowy kredytowej, są zwykle trudno dostępne, przez co nie są w kalkulacjach uwzględniane.

RRSO można rozdzielić na dwa składniki: hurtową cenę pieniądza, jaką jest Wibor, oraz nadwyżkę ponad Wibor, którą bank pobiera na pokrycie kosztów własnych i osiągnięcie zysku; autorzy przyjęli dla niej nazwę „marża rzeczywista”. Można to wyrazić następującą formułą:

\section{Rzeczywista Roczna Stopa Oprocentowania $=$ Wibor + marża rzeczywista}

Tak określona marża rzeczywista zawiera zarówno marżę podstawową (składającą się wraz z Wiborem na oprocentowanie, jeśli określono je jako zmienne), jak również pozostałe opłaty, które z kwot płaconych w nieregularnych odstępach czasu (np. prowizja, uiszczana tylko przy udzielaniu kredytu) zostają przeliczone na składnik rocznej stopy procentowej, dotyczącej całego okresu kredytowania.

Kalkulację RRSO wykonuje się na dany moment czasowy (dzień przedstawienia oferty kredytu lub podpisania umowy kredytowej). W przypadku oprocentowania zmiennego konieczne jest przy tym założenie, że Wibor w przyszłości nie będzie się zmieniał, dlatego w powyższej formule należy wstawiać wartość Wiboru na dany dzień. Porównywalność marży rzeczywistej różnych kredytów zapewnia się natomiast przez przyjęcie jednego i tego samego Wiboru we wszystkich kalkulacjach, np. Wiboru 3M (nawet jeśli pierwotnie cena kredytu odnosiła się do innego, np. Wiboru 1M).

O ile już sama RRSO jest miarą „dobrze” wyrażającą koszt kredytu, o tyle wyznaczona opisaną powyżej metodą marża rzeczywista pozwala badać tę część tej stopy, która stanowi dla banku nadwyżkę ponad hurtową cenę pieniądza, czyli de facto pokrycie kosztów własnych jego funkcjonowania oraz rekompensatę za podjęte ryzyko. Marża rzeczywista pozwala zbadać, czy nadwyżka ta ulega zmianom w długim okresie (a jeśli tak, to jakim) po odrzuceniu elementu niezależnego od polityki cenowej danego banku, tj. Wiboru, który również jest składnikiem zmiennym w czasie. To z kolei pozwala ocenić stosunek banków do ryzyka kredytowego w długim okresie.

\section{Szacowanie ceny pożyczki między podmiotami powiązanymi - studium przypadku}

Badania empiryczne przeprowadzono na podstawie dokumentacji cen transferowych, zwanej dalej „dokumentacją podatkową”, przygotowanej przez autorów niniejszego artykułu. Dokumentacja dotyczy transakcji pożyczek zawartych 
między podmiotami powiązanymi, na której wykorzystanie w niniejszej pracy uzyskano zgodę. Było to kilka pożyczek o wartości pomiędzy $100000 \mathrm{zł}$ a 300000 zł każda. Pożyczki udzielane były spółce osobowej, zwanej dalej „Spółką A”, z siedzibą w Polsce, przez jej wspólników, zwanych dalej „pożyczkodawcami” lub ,pożyczkodawcą", mieszkających również w Polsce. Pożyczek udzielono w walucie polskiej, początkowo na krótki okres (rok, trzy lata), który potem przedłużano na kolejne lata stosownymi aneksami, wydłużając czas trwania transakcji znacznie ponad pięć lat. Poza oprocentowaniem nie określono innych składników odpłatności za udzielony kapitał. Umowy nie zawierały również żadnych postanowień o zabezpieczeniach spłaty zobowiązania. Dokumentacja podatkowa obejmuje lata 2010-2017, natomiast przy analizie porównawczej zakres uwzględnianych danych rozszerzono o okres starszy (od roku 2004) oraz najświeższy (część roku 2018).

Dokumentacja dotycząca opisanych transakcji zawiera wszystkie wymagane przepisami elementy, takie jak opis powiązań, szczegóły transakcji, analiza funkcji, aktywów i ryzyk oraz uzasadnienie wyboru metody i sposobu kalkulacji oprocentowania. W przeciwieństwie do innych transakcji, takich jak dostawy wyrobów czy świadczenie usług, w przypadku umów pożyczek analiza funkcji i aktywów jest dość prosta, bowiem głównym aktywem jest powierzany kapitał, a głównymi funkcjami - powierzenie, przyjęcie, administrowanie i spłata tego kapitału. Szczególne znaczenie ma natomiast analiza ryzyk, którą w dokumentacji przedstawiono w postaci tabelarycznej (Tabela 1).

Tabela 1. Zestawienie ryzyk ponoszonych przez strony transakcji pożyczki

\begin{tabular}{|l|c|c|}
\hline \multicolumn{1}{|c|}{ Ryzyka } & Pożyczkodawca & Spółka \\
\hline Ryzyko wypowiedzenia umów przed terminem & $\mathrm{X}$ & $\mathrm{X}$ \\
\hline Ryzyko utraty powierzonego kapitału & $\mathrm{X}$ & \\
\hline Ryzyko nieotrzymania odsetek od kapitału & $\mathrm{X}$ & \\
\hline Ryzyko opóźnień spłaty kapitału lub odsetek & $\mathrm{X}$ & \\
\hline $\begin{array}{l}\text { Ryzyko utraty korzyści związanych z alternatywnym wykorzysta- } \\
\text { niem kapitału }\end{array}$ & $\mathrm{X}$ & \\
\hline Ryzyko konieczności zabezpieczenia płynności & & $\mathrm{X}$ \\
\hline Ryzyko braku środków na terminową spłatę pożyczek i/lub odsetek & & $\mathrm{X}$ \\
\hline Ryzyko niekorzystnego rozwoju struktury kapitałowej & $\mathrm{X}$ \\
\hline $\begin{array}{l}\text { Ryzyko ponoszenia kosztów znacznie przekraczających koszty } \\
\text { alternatywnych źródeł kapitału obcego }\end{array}$ & $\mathrm{X}$ & $\mathrm{X}$ \\
\hline Ryzyko zmian stóp procentowych & & \\
\hline
\end{tabular}

Źródło: dokumentacja podatkowa Spółki A.

Oprócz ujęcia tabelarycznego dokumentacja zawiera szczegółowy opis ryzyk ponoszonych przez każdą ze stron transakcji. Ryzyka ponoszone przez pożyczkodawcę opisano następująco: 
- Ryzyko wypowiedzenia umów przed terminem przez Spółkę - dla pożyczkodawcy oznacza to uzyskanie odsetek mniejszych (za krótszy okres), niż oczekiwał, czyli dochód mniejszy od przewidywanego. Wiąże się z tym ryzyko prowadzenia sporu co do wysokości odsetek, bowiem umowy nie przewidują sposobu wyliczenia odsetek w przypadku spłaty przedterminowej, a co za tym idzie - ponoszenia kosztów tego sporu (procedury sądowe, windykacja); z uwagi na powiązanie pożyczkodawcy ze Spółką to ryzyko jest jednak minimalne - dochowanie warunków umów leży w interesie obu stron.

- Ryzyko utraty powierzonego kapitału w sytuacji, gdy kondycja Spółki pogorszy się na tyle, że nie będzie ona w stanie spłacić zaciągniętych pożyczek (w szczególności w przypadku upadłości/bankructwa). Wiąże się z tym ryzyko prowadzenia sporu i ponoszenia kosztów tego sporu (procedury sądowe, windykacja). Ze względu na brak zabezpieczeń ryzyko utraty powierzonego kapitału jest głównym ryzykiem po stronie pożyczkodawcy, uzasadniającym odpowiednio wysoką cenę powierzanego kapitału.

- Ryzyko nieotrzymania odsetek od kapitału w sytuacji, gdy kondycja Spółki pogorszy się na tyle, że nie będzie ona w stanie spłacić odsetek od kapitału (w szczególności w przypadku upadłości/bankructwa). Wiąże się z tym ryzyko prowadzenia sporu i ponoszenia kosztów tego sporu (procedury sądowe, windykacja).

- Ryzyko opóźnień spłaty kapitału lub odsetek w sytuacji, gdy kondycja Spółki pogorszy się na tyle, że nie będzie ona w stanie terminowo spłacać zaciągniętych pożyczek. Wiąże się z tym ryzyko prowadzenia sporu i ponoszenia jego kosztów (procedury sądowe, windykacja).

- Ryzyko utraty korzyści związanych z alternatywnym wykorzystaniem kapitału, które może się ziścić, gdy pożyczkodawca nie mógłby skorzystać z okazji lepszego alokowania kapitału ze względu na jego zamrożenie w Spółce w postaci pożyczek.

- Ryzyko konieczności zabezpieczenia płynności. Przekazując kapitał Spółce, pożyczkodawca obniżył własną płynność finansową; gdyby nagle potrzebował takiej sumy, a nie chciał żądać od Spółki przedterminowej spłaty, musiałby pozyskać pieniądze z innego źródła, ponosząc stosowne koszty takiego finansowania.

- Ryzyko spadku stóp procentowych, skutkujące obniżaniem oprocentowania pożyczek - dla pożyczkodawcy oznacza to uzyskiwanie z pożyczek dochodów mniejszych niż oczekiwał. 
Natomiast ryzyka ponoszone przez Spółkę opisano następująco:

- Ryzyko wypowiedzenia umów przed terminem przez pożyczkodawcę-dla Spółki oznacza to konieczność przedterminowej spłaty kapitału lub prowadzenie sporu co do zasadności żądania jego zwrotu, a także wysokości należnych odsetek, bowiem umowy nie przewidują takiej sytuacji. Wiąże się z tym ryzyko ponoszenia kosztów tego sporu (procedury sądowe). $\mathrm{Z}$ uwagi na powiązanie pożyczkodawcy ze Spółką to ryzyko jest jednak minimalne - dochowanie warunków umowy leży w interesie obu stron.

- Ryzyko braku środków na terminową spłatę pożyczek i/lub odsetek, które oznacza niewywiązanie się z postanowień umów i jest podstawą do sporu, którego skutkiem będą zwiększone koszty (odsetki karne, koszty sądowe), jeszcze bardziej pogarszające kondycję finansową Spółki.

- Ryzyko niekorzystnego rozwoju struktury kapitałowej. W przypadku kurczenia się kapitału własnego fakt posiadania pożyczek oraz rosnące odsetki od nich powodują nieproporcjonalnie szybkie wzrastanie wskaźnika zadłużenia (stosunek zobowiązań do sumy pasywów), co jest źle postrzegane przez innych kapitałodawców czy kontrahentów i może spowodować pogorszenie się sytuacji Spółki w relacjach z tymi podmiotami.

- Ryzyko ponoszenia kosztów znacznie przekraczających koszty alternatywnych źródeł kapitału obcego - zamiast pożyczek Spółka mogła pozyskać tańsze finansowanie, np. kredyty (akceptując jednak inne ich wady, np. konieczne zabezpieczenie).

- Ryzyko wzrostu stóp procentowych, skutkujące wzrostem oprocentowania pożyczek - dla Spółki oznacza to ponoszenie kosztów finansowania wyższych niż pierwotnie były one przewidywane.

W treści dokumentacji podkreślono, że głównym ryzykiem związanym $\mathrm{z}$ transakcją jest występujące po stronie pożyczkodawcy ryzyko utraty powierzonego kapitału, wynikające $\mathrm{z}$ braku zabezpieczeń. Zaznaczono również, że ryzyko to uzasadnia odpowiednio wysoką cenę powierzanego kapitału, jaka powinna być zastosowana w przedmiotowej transakcji.

Do określenia rynkowej wysokości oprocentowania pożyczek wykorzystano metodę porównywalnej ceny niekontrolowanej, na co pozwoliła dostępność danych o porównywalnych transakcjach niekontrolowanych - kredytach zaciągniętych przez Spółkę A w polskich bankach; bazę tę powiększono o kredyty zaciągnięte przez inną spółkę (zwaną dalej „Spółką B”), z branży innej niż Spółka A, ale charakteryzującą się podobną skalą działalności i kondycją finansową. Łącznie pozyskano w ten sposób dane o ponad 20 transakcjach dotyczących udzielania kredytów na przestrzeni 15 lat. Kwoty kredytów zawierały się w przedziale od $50000 \mathrm{zł}$ do $5000000 \mathrm{zl}$, a okresy kredytowania - od 8 miesięcy do 5 lat. Analizę wzbogacono danymi statystycznymi NBP. 
W przypadku badanej pożyczki kwestię ryzyka autorzy uznali za bardzo istotną. Trzeba jednak zwrócić uwagę na to, że użycie metod wskazanych w literaturze w części teoretycznej, jak i korzystanie z baz danych LoanConnector, czy też zastosowanie procedury z wykorzystaniem wskaźnika Altman's Z-Score należy uznać za niewłaściwe ze względu na różnice kwoty pożyczki oraz wielkości i specyfiki rynku. Umowa pożyczki została zawarta między krajowymi podmiotami powiązanymi, natomiast wskazane metody polegają na korzystaniu z informacji pochodzących głównie z rynków zagranicznych. Tymczasem wytyczne OECD wskazują, że zasada porównywalności wymaga, aby rynki, na których działają przedsiębiorstwa niezależne i powiązane, były porównywalne, a różnice nie miały istotnego wpływu na cenę lub by można było dokonać odpowiednich korekt. Geograficznie określony rynek stanowi inną okoliczność ekonomiczną, która może mieć wpływ na porównywalność transakcji (Górski, Zbroiński 2016). Zdaniem autorów rynek finansowy jest właśnie takim rodzajem rynku, w przypadku którego położenie geograficzne odgrywa znaczącą rolę. Wynika to między innymi z faktu, że na ustalanie stóp procentowych ma wpływ wiele czynników, np. inflacja, polityka fiskalna czy monetarna. W związku z tym, badając rynkowość warunków pożyczek zawieranych na danym rynku między krajowymi podmiotami powiązanymi, niezależnie od tego, czy chodzi o Polskę, czy o inny kraj, zdaniem autorów nie powinno się bezrefleksyjnie sięgać do informacji z LoanConnector czy wskaźnika Altman's Z-Score. Oczywiście jeśli baza zawiera informacje dotyczące określonego (np. krajowego) rynku finansowego, to jej wykorzystanie jako źródła pozyskania danych może być uzasadnione.

Natomiast jeśli chodzi o korzystanie $\mathrm{z}$ danych Catalyst, to trzeba zwrócić uwagę na wartości emisji obligacji - są one na tyle duże, że nie można ich wykorzystać do określenia cen pożyczek o wartości kilkuset tysięcy złotych.

Co do zasady, określenia ceny transakcji powinno się dokonywać przez porównanie do transakcji rynkowych zawieranych w podobnym okresie. Umowa pożyczki jest jednak transakcją specyficzną, bowiem cena odnosi się nie tylko do ilości dostarczanego „towaru” (kapitału), lecz również do konkretnego okresu, na jaki jest on udostępniany. Należy zatem ustalać cenę w odniesieniu do poszczególnych okresów (zwykle lat kalendarzowych) trwania umowy pożyczki. Uzasadnia to wykorzystanie w porównaniu umów kredytowych zawieranych we wszystkich latach, dla jakich je pozyskano. W szczególności należy podkreślić, że uwzględnienie w porównaniu kredytów zaciągniętych w różnych latach pozwoliło stwierdzić, że zakres stosowanych marż rzeczywistych w przypadku tych kredytów jest względnie stały w czasie, co jest bardzo istotną okolicznością przy kalkulowaniu rynkowych cen pożyczek.

Dla wszystkich kredytów uwzględnionych w przedmiotowej dokumentacji wyznaczono RRSO, zgodnie z metodą omówioną w części „Cena kapitału dłużnego i jej porównywalność", trzymając się przy tym następujących założeń: 
1. Jeśli w umowie podano wprost oprocentowanie na dzień umowy, to płatności odsetek wyliczano na podstawie tego oprocentowania. W przeciwnym razie oprocentowanie ustalano jako właściwą stawkę Wibor $(3 \mathrm{M}$ lub $1 \mathrm{M}) \mathrm{w}$ dniu podpisania umowy, powiększoną o marżę określoną w umowie.

2. Oprocentowanie traktowano jako niezmienne w całym okresie kredytu, bowiem RRSO wyznaczane jest na dzień zawarcia umowy. W całym okresie spłacania kredytu rzeczywista cena jest zmienna ze względu na zmiany Wiboru, ale zmienność ta jest trudna do określenia, dlatego trzeba przyjąć założenie o braku zmienności.

3. W przypadku wszystkich kredytów zakładano ich maksymalne wykorzystanie już od miesiąca, w którym zostały zaciągnięte (z jednym wyjątkiem), niezależnie od tego, w jakim stopniu kredytobiorca rzeczywiście wykorzystywał kredyt po zawarciu umów. Konsekwencją tego założenia jest m.in. nieuwzględnianie w kalkulacji RRSO prowizji za gotowość (za zaangażowanie), która w takim przypadku nie ma zastosowania.

4. W przypadku dwóch kredytów udzielonych na innowacyjne inwestycje nie uwzględniano wpływu środków stanowiących dofinansowanie inwestycji środkami publicznymi, bowiem $\mathrm{w}$ momencie zawierania umowy ich otrzymanie nie było w pełni zagwarantowane. Prawo banków do wykorzystania tych środków na pokrycie kredytu uwzględniono natomiast jako dodatkowe zabezpieczenie podnoszące ,jakość" kredytu i obniżające ryzyko ponoszone przez te banki.

Należy podkreślić, że uwzględnienie niepełnego wykorzystania kredytów (o czym mowa w punkcie 3 powyżej) lub wpływu dofinansowania publicznego (punkt 4) spowodowałoby relatywne zwiększenie udziału prowizji w kosztach tych kredytów, przez co ich RRSO, rozumiana jako cena za maksymalne przyznawane przez bank finansowanie, byłaby niejako sztucznie zawyżona.

W przedstawiony powyżej sposób wyznaczono rzeczywiste ceny uzgodnione przez banki i kredytobiorców w poszczególnych dniach zawarcia umów kredytowych. Jak wspomniano, każda z takich cen (RRSO) zawiera składnik wyrażający „hurtową” cenę pieniądza, po jakiej (upraszczając) bank kupuje pieniądz w celu odsprzedania go kredytobiorcy, oraz rzeczywistą marżę banku, wyższą od marży określonej w umowie o odpowiednio wkalkulowane dodatkowe koszty (prowizje). Dla każdego kredytu wyznaczono więc marżę rzeczywistą, stosując wzór:

Marża rzeczywista $=$ Rzeczywista Roczna Stopa Oprocentowania - Wibor 3M w danym dniu 
Jak wskazano w części „Cena kapitału dłużnego i jej porównywalność”, przyjęcie jednego Wiboru (wybrano 3M) jest niezbędne dla zapewnienia jednolitości (porównywalności) wyznaczonych marż. Ten sam Wibor jest więc stopą odniesienia w przypadku kalkulowania cen pożyczek.

Aby określić oprocentowanie, jakie ustaliłyby między sobą niezależne podmioty przy udzielaniu przedmiotowych pożyczek, konieczne jest odrębne uwzględnienie stawek Wibor oraz marży, jaką zaakceptowałyby owe podmioty niezależne. Notowania stawek Wibor są łatwo dostępne, można szybko ustalić stosowne średnie dla poszczególnych lat. Bardziej skomplikowanym zagadnieniem jest określenie właściwej marży, którą należy do tych Wiborów doliczyć. Wysokość marż stosowanych przez banki jest silnie związana z ponoszonym ryzykiem, które z kolei redukowane jest przez stosowanie zabezpieczeń. W przypadku przedmiotowych pożyczek, jak i kredytów służących za odniesienie do ustalenia rynkowych poziomów cen, nie mają natomiast znaczenia kwestie dotyczące waluty pożyczki/kredytu (i wynikających stąd ryzyk), bowiem wszystkie one zaciągane były i spłacane w walucie polskiej.

Szczegółowa analiza kredytów z wyszczególnieniem cech determinujących ryzyko ponoszone przez kredytodawców pozwoliła wyodrębnić pod tym względem dwie wyraźnie odróżniające się klasy kredytów, umownie określonych jako „dobrze zabezpieczone” i „średnio zabezpieczone”. Do klasy kredytów dobrze zabezpieczonych zaliczono te, w przypadku których zastosowano co najmniej dwie z głównych form zabezpieczeń. Zastosowanie minimum dwóch form powoduje, że w razie problemów ze spłatą kredytu bank ma możliwość dość szybko i z dużą pewnością zaspokoić swoje roszczenia. Natomiast cztery umowy kredytowe zawierające postanowienia o jednej tylko formie zabezpieczenia zostały określone jako średnio zabezpieczone - ryzyko banku w razie problemów ze spłatą jest $\mathrm{w}$ ich przypadku zdecydowanie wyższe niż w przypadku kredytów dobrze zabezpieczonych. Wyniki badania przedstawiono na Wykresie 1.

Wykres 1 pokazuje, że rzeczywiste marże zastosowane w przypadku kredytów mieszczą się w dość wąskich przedziałach:

- od 1,78\% do 4,31\% dla kredytów dobrze zabezpieczonych, oraz

- od $10,70 \%$ do $12,59 \%$ dla kredytów średnio zabezpieczonych.

Skupienie rzeczywistych marż w wąskich przedziałach pozwala na wyciągnięcie wniosku, że na ich wysokość wpływa przede wszystkim sposób (stopień) zabezpieczenia kredytu, a w zdecydowanie mniejszym stopniu inne jego cechy, takie jak kwota, okres, charakter i cel finansowania czy forma spłat. W odniesieniu do kredytów dobrze zabezpieczonych można też zauważyć, że zakres marż nie zmienia się w czasie, mimo dość szerokiego zakresu uwzględnionych lat. Ponownie należy podkreślić, że uzasadnia to wykorzystanie do porównania umów kredytowych zawartych w szerokim zakresie czasowym. Brak kredytów 
średnio zabezpieczonych poza okresem 2007-2014 uniemożliwia odpowiedź na pytanie o to, czy podobna stabilność zakresu marż charakteryzuje również tę klasę kredytów.

Wykres 1. Marże rzeczywiste (w \%) wyznaczone dla kredytów zaciągniętych przez Spółkę A i Spółkę B

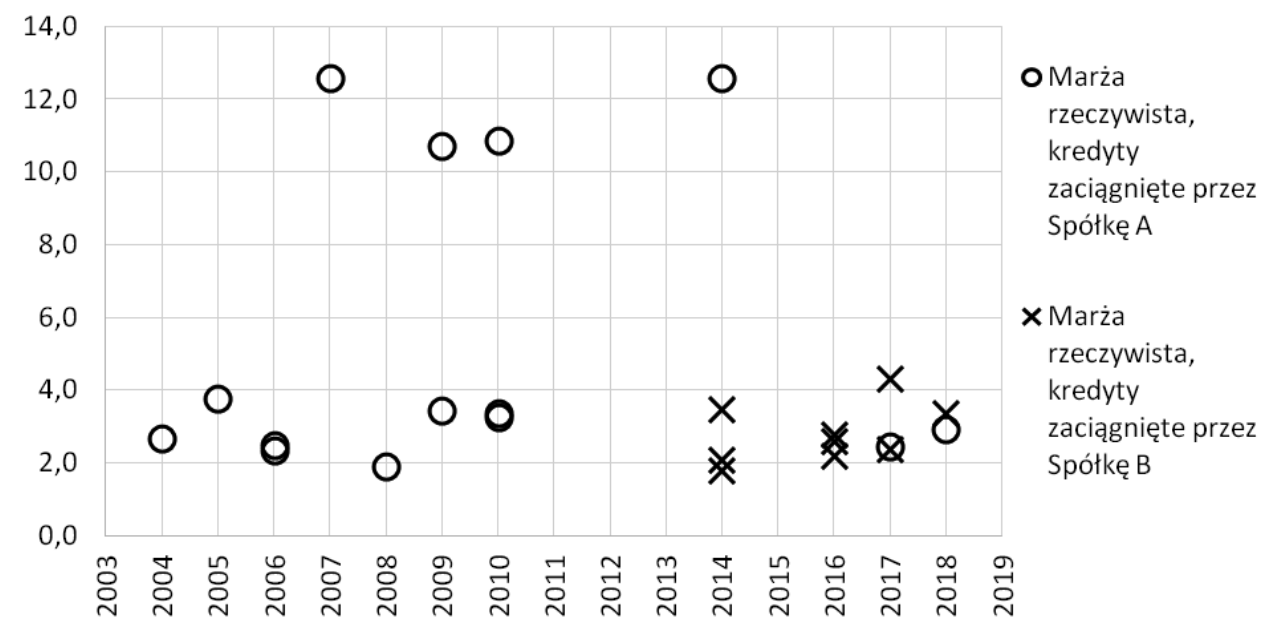

Źródło: dokumentacja podatkowa Spółki A.

W kolejnej części dokumentacji wskazano, że określenie rynkowych cen pożyczek musi uwzględniać różnicę w jej zabezpieczeniu w porównaniu z kredytami. Obrazuje to Tabela 2.

Tabela 2. Zakres marż rzeczywistych dla kredytów o różnym poziomie zabezpieczenia, udzielonych Spółkom A i B

\begin{tabular}{|l|c|c|c|}
\hline \multicolumn{1}{|c|}{$\begin{array}{c}\text { Klasa } \\
\text { finansowania }\end{array}$} & \multicolumn{1}{|c|}{$\begin{array}{c}\text { Kredyty dobrze } \\
\text { zabezpieczone }\end{array}$} & $\begin{array}{c}\text { Kredyty średnio } \\
\text { zabezpieczone }\end{array}$ & $\begin{array}{c}\text { Pożyczki } \\
\text { od wspólników }\end{array}$ \\
\hline Zabezpieczenie & $\begin{array}{l}\text { wysokie - co najmniej dwie } \\
\text { z głównych form zabezpie- } \\
\text { czeń }\end{array}$ & $\begin{array}{l}\text { średnie - jedna forma } \\
\text { zabezpieczenia }\end{array}$ & brak zabezpieczeń \\
\hline $\begin{array}{l}\text { Zakres marż } \\
\text { rzeczywistych }\end{array}$ & $1,78-4,31 \%$ & $10,70-12,59 \%$ & $\begin{array}{l}\text { odpowiednio wyższy } \\
\text { od kredytów dobrze } \\
\text { i średnio zabezpieczo- } \\
\text { nych }\end{array}$ \\
\hline
\end{tabular}

Źródło: dokumentacja podatkowa Spółki A.

Z porównania jednoznacznie wynika, że pożyczki, jako niezabezpieczone w ogóle, powinny być odpowiednio droższe od kredytów, zarówno tych dobrze, jak i tych średnio zabezpieczonych. Odpowiednio wysoka marża musi bowiem rekompensować ponoszenie wyższego ryzyka. Warto przy tym zauważyć, że pełen dostęp 
do informacji o spółce-pożyczkobiorcy tylko pozornie redukuje ryzyko ponoszone przez wspólnika bardziej niż w przypadku banków. W rzeczywistości nie jest to czynnik istotnie wpływający na cenę, bowiem banki mają prawo (a wręcz obowiązek) uzyskiwać od kredytobiorcy wszelkie informacje istotne dla oceny zdolności kredytowej, co gwarantują im odpowiednie zapisy umów oraz regulacje prawne, dlatego mają o kredytobiorcy zakres informacji nie gorszy niż wspólnicy (wyjąwszy zabronione prawem przypadki zatajeń i dezinformacji, których tu nie można zakładać). Należy przyjąć, że takiego samego dostępu do informacji zażądałby niezależny podmiot udzielający spółce pożyczki, a ewentualne koszty ich pozyskania i przetworzenia wkalkulowałby, podobnie jak banki, w odpowiednio wysoką cenę finansowania.

O ile oczywiste jest, że oprocentowanie zupełnie niezabezpieczonych pożyczek musiałoby bazować na marży wyższej niż marże kredytów zabezpieczonych, o tyle trudno określić wysokość tej marży. Można wskazać, że kredyty średnio zabezpieczone były o ok. 8-9 punktów procentowych (p.p.) droższe od kredytów dobrze zabezpieczonych, ale nie pozwala to wyznaczyć dodatku marży za całkowity brak zabezpieczenia, ponieważ:

1. trudno ocenić, w jakim stopniu dodatek marży za „słabsze” zabezpieczenie przekłada się na dodatek marży za całkowity brak zabezpieczenia;

2. stałość zakresu marż w czasie stwierdzono tylko w przypadku kredytów dobrze zabezpieczonych, natomiast nie ma pewności, czy przed $2007 \mathrm{r}$. i po 2014 r. marże kredytów średnio zabezpieczonych pozostawały w podobnym zakresie, co marże stwierdzone w latach 2007-2014.

Wobec tego do wyznaczenia dodatku marży wykorzystano dane o średnich oprocentowaniach kredytów, publikowane przez Narodowy Bank Polski (NBP 2018). Najbardziej reprezentatywne spośród tych statystyk byłyby oprocentowania kredytów udzielanych przedsiębiorstwom niefinansowym, jednak nie można z nich skorzystać, ponieważ dla okresu przed rokiem 2010 występują liczne braki danych, a oprocentowania nie są wyznaczone jako stopa rzeczywista (a taka jest potrzebna do porównania). Główny problem polega jednak na tym, że nie podzielono kredytów na klasy ryzyka według zabezpieczenia - podano tylko zbiorczą informację dotyczącą wszystkich rodzajów kredytów, również takich, które były bardzo dobrze zabezpieczone. Do analizy wykorzystano zatem dane o kredytach udzielanych gospodarstwom domowym i instytucjom niekomercyjnym działającym na rzecz gospodarstw domowych. Dane te wyrażone są jako stopy rzeczywiste, czyli wyznaczone zgodnie z metodologią RRSO. Wybrano statystyki dotyczące średnich oprocentowań nowych i renegocjowanych umów złotowych. $\mathrm{Na}$ podstawie danych miesięcznych wyznaczono średnie roczne.

Kluczowe dla analizy jest zestawienie dwóch rodzajów kredytów:

- na cele konsumpcyjne (bez kredytów o charakterze bieżącym),

- na nieruchomości mieszkaniowe. 
Pierwsze są zwykle kredytami bez zabezpieczenia (lub o słabym zabezpieczeniu). Drugie to zwykle kredyty hipoteczne, czyli zabezpieczone na finansowanej nieruchomości wpisem do hipoteki, co jest bardzo dobrym rodzajem zabezpieczenia. Kredyty te odróżnia również zakres badania zdolności kredytowej - w przypadku kredytów mieszkaniowych rygorystycznie przestrzega się badania źródeł dochodów kredytobiorców i ich stabilności. Powoduje to, że te dwie klasy kredytów są klasami skrajnymi, jeśli chodzi o ryzyko ponoszone przez kredytodawcę.

Uwzględniając powyższe przyjęto, że różnica ryzyka pomiędzy niezabezpieczoną pożyczką, jakiej udzieliłby spółce podmiot niezależny (analogiczną do pożyczek od wspólników) a dobrze zabezpieczonymi kredytami przyjętymi do porównania odpowiada różnicy ryzyka pomiędzy kredytami konsumpcyjnymi a kredytami mieszkaniowymi udzielanymi osobom fizycznym. Stąd z kolei wynika, że różnica między marżą rzeczywistą dla pożyczek a marżą rzeczywistą kredytów powinna być w poszczególnych latach równa różnicy marż rzeczywistych pomiędzy kredytami konsumpcyjnymi i mieszkaniowymi. Wyznaczenie tej różnicy prezentuje Tabela 3.

Tabela 3. Średnie oprocentowanie i marże rzeczywiste dla kredytów na cele konsumpcyjne i na nieruchomości mieszkaniowe oraz premia za dodatkowe ryzyko (dane w \%)

\begin{tabular}{|l|c|c|c|c|c|c|c|c|c|}
\hline \multicolumn{1}{|c|}{ Okres } & $\mathbf{2 0 1 0}$ & $\mathbf{2 0 1 1}$ & $\mathbf{2 0 1 2}$ & $\mathbf{2 0 1 3}$ & $\mathbf{2 0 1 4}$ & $\mathbf{2 0 1 5}$ & $\mathbf{2 0 1 6}$ & $\mathbf{2 0 1 7}$ & $\begin{array}{c}\mathbf{0 1 . 2 0 1 8} \\
\mathbf{- 0 7 . 2 0 1 8}\end{array}$ \\
\hline $\begin{array}{l}\text { Oprocentowanie } \\
\text { - cele konsumpcyjne }\end{array}$ & 21,64 & 21,83 & 22,29 & 20,85 & 19,27 & 15,62 & 15,22 & 14,37 & 13,86 \\
\hline $\begin{array}{l}\text { Oprocentowanie } \\
\text { - nieruchomości } \\
\text { mieszkaniowe }\end{array}$ & 7,13 & 7,01 & 7,39 & 5,86 & 5,49 & 4,64 & 4,63 & 4,61 & 4,59 \\
\hline Wibor 3M & 3,93 & 4,54 & 4,91 & 3,03 & 2,52 & 1,75 & 1,70 & 1,73 & 1,71 \\
\hline $\begin{array}{l}\text { Marża rzeczywista } \\
\text { - cele konsumpcyjne }\end{array}$ & 17,71 & 17,29 & 17,38 & 17,82 & 16,75 & 13,87 & 13,52 & 12,64 & 12,15 \\
\hline $\begin{array}{l}\text { Marża rzeczywista } \\
\text { - nieruchomości } \\
\text { mieszkaniowe }\end{array}$ & 3,20 & 2,47 & 2,48 & 2,83 & 2,97 & 2,89 & 2,93 & 2,88 & 2,88 \\
\hline $\begin{array}{l}\text { Różnica (premia za } \\
\text { dodatkowe ryzyko) }\end{array}$ & 14,51 & 14,82 & 14,90 & 14,99 & 13,78 & 10,97 & 10,59 & 9,77 & 9,27 \\
\hline
\end{tabular}

Źródło: dokumentacja podatkowa Spółki A.

Wyznaczone dla kredytów konsumpcyjnych i mieszkaniowych marże rzeczywiste, zestawione z marżami rzeczywistymi kredytów wziętych do porównania, przedstawia Wykres 2. 
Wykres 2. Marże rzeczywiste (w \%) wyznaczone dla kredytów zaciągniętych przez Spółkę A i przez Spółkę B oraz dla kredytów konsumpcyjnych i mieszkaniowych udzielanych przez polskie banki

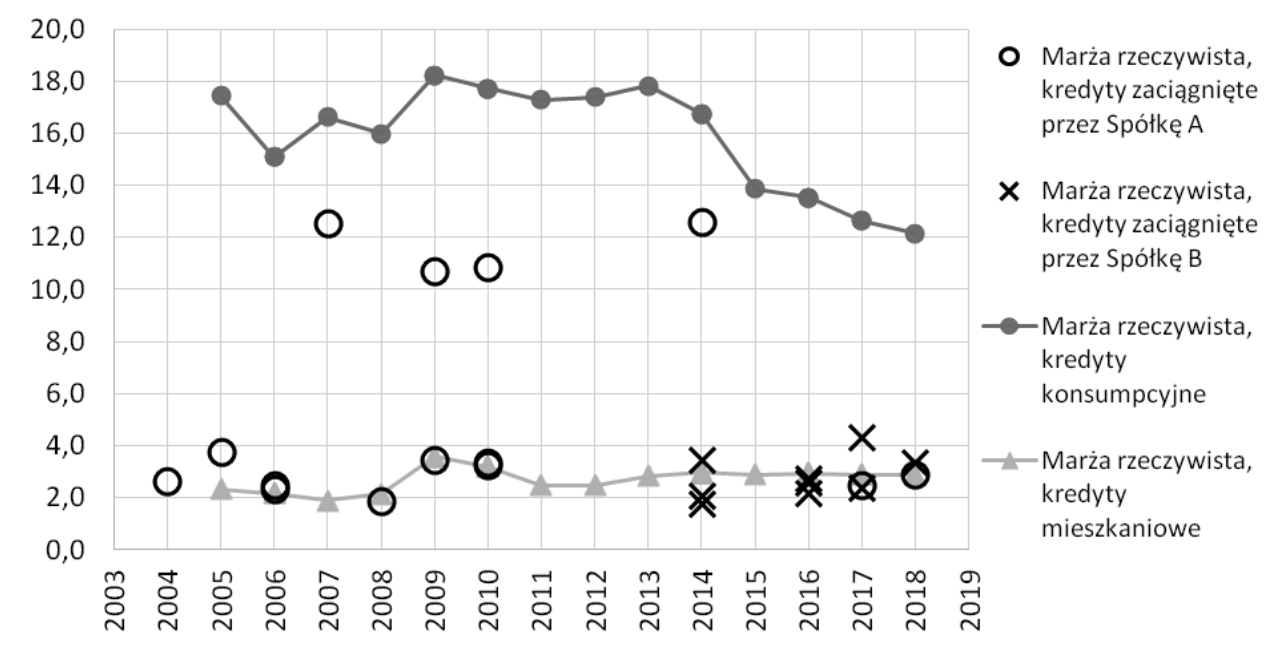

Źródło: dokumentacja podatkowa Spółki A.

Dane przedstawione na Wykresie 2 pozwalają stwierdzić co następuje:

1. marże na kredytach mieszkaniowych są względnie stałe, podobnie jak marże na analizowanych kredytach dobrze zabezpieczonych, a zakresy tych marż praktycznie się ze sobą pokrywają;

2. marże na kredytach konsumpcyjnych są wyższe, niż na analizowanych kredytach średnio zabezpieczonych, co jest zgodne $\mathrm{z}$ ich oceną pod względem ryzyka;

3. marże na kredytach konsumpcyjnych są dużo niższe po 2014 roku, a ich trend od 2014 jest malejący, co sugeruje podobne zmiany w przypadku marż na kredytach średnio zabezpieczonych; wobec braku danych o kredytach średnio zabezpieczonych w innych latach nie należy ich uwzględniać przy wycenianiu oprocentowania pożyczek.

W dalszej części dokumentacji dokonano wyznaczenia ceny, jaką Spółka A musiałaby zapłacić niezależnemu podmiotowi za pożyczkę udzieloną bez zabezpieczenia (na warunkach analogicznych do pożyczek udzielonych przez wspólników). Cenę tę określono jako stopę procentową, na którą składają się trzy składniki:

- Wibor, stanowiący „hurtową” cenę na rynku pieniądza (jako stopę odniesienia przyjęto Wibor 3M); jest to element zmienny w czasie;

- bazowa marża za ryzyko, której zakres wyznaczają marże rzeczywiste zidentyfikowane dla kredytów dobrze zabezpieczonych (od 1,78\% do $4,31 \%)$; jest to element stały w czasie; 
- marża za dodatkowe ryzyko, wynikająca z braku zabezpieczeń, a skalkulowana jako różnica między marżami dla kredytów konsumpcyjnych i mieszkaniowych udzielanych osobom fizycznym; jest to element zmienny w czasie.

Zakres wyznaczonych według powyższych wytycznych rynkowych stawek oprocentowania pożyczek w stosownych okresach przedstawiono w Tabeli 4. Wibor $3 \mathrm{M}$ oraz dodatkowe marże za ryzyko wyznaczono jako średnie za właściwe okresy. Stawkę sugerowaną ustalono z wykorzystaniem dolnej granicy bazowej marży za ryzyko $(1,78 \%)$ i zaokrąglono $\mathrm{w}$ górę do dziesiętnych części punktu procentowego.

Tabela 4. Oprocentowanie pożyczek udzielonych Spółce A, ustalone wg warunków rynkowych (dane $\mathrm{w} \%$ )

\begin{tabular}{|l|r|r|r|r|r|r|r|r|}
\hline \multicolumn{1}{|c|}{ Okres } & $\begin{array}{r}\text { Część } \\
\mathbf{2 0 1 0}\end{array}$ & $\mathbf{2 0 1 1}$ & $\mathbf{2 0 1 2}$ & $\mathbf{2 0 1 3}$ & $\mathbf{2 0 1 4}$ & $\mathbf{2 0 1 5}$ & $\mathbf{2 0 1 6}$ & $\mathbf{2 0 1 7}$ \\
\hline Wibor 3M & 3,92 & 4,54 & 4,91 & 3,03 & 2,52 & 1,75 & 1,70 & 1,73 \\
\hline $\begin{array}{l}\text { Bazowa marża za ryzyko } \\
\text { - dolna granica }\end{array}$ & 1,78 & 1,78 & 1,78 & 1,78 & 1,78 & 1,78 & 1,78 & 1,78 \\
\hline $\begin{array}{l}\text { Bazowa marża za ryzyko } \\
\text { - górna granica }\end{array}$ & 4,31 & 4,31 & 4,31 & 4,31 & 4,31 & 4,31 & 4,31 & 4,31 \\
\hline Marża za dodatkowe ryzyko & 14,68 & 14,82 & 14,90 & 14,99 & 13,78 & 10,97 & 10,59 & 9,77 \\
\hline $\begin{array}{l}\text { Oprocentowanie pożyczki } \\
\text { - dolna granica }\end{array}$ & 20,38 & 21,14 & 21,59 & 19,80 & 18,08 & 14,50 & 14,07 & 13,28 \\
\hline $\begin{array}{l}\text { Oprocentowanie pożyczki } \\
\text { - górna granica }\end{array}$ & 22,91 & 23,67 & 24,12 & 22,33 & 20,61 & 17,03 & 16,60 & 15,81 \\
\hline $\begin{array}{l}\text { Oprocentowanie pożyczki } \\
\text { - sugerowane }\end{array}$ & $\mathbf{2 0 , 4 0}$ & $\mathbf{2 1 , 2 0}$ & $\mathbf{2 1 , 6 0}$ & $\mathbf{1 9 , 8 0}$ & $\mathbf{1 8 , 1 0}$ & $\mathbf{1 4 , 5 0}$ & $\mathbf{1 4 , 1 0}$ & $\mathbf{1 3 , 3 0}$ \\
\hline
\end{tabular}

* Dla roku 2010 kalkulacja dotyczy tylko niepełnego miesiąca, w którym trwała transakcja pożyczki. Źródło: opracowanie własne na podstawie dokumentacji Spółki A.

Jak pokazuje Tabela 4, oprocentowanie pożyczki ustalone na warunkach rynkowych jest znacząco wyższe od bazowych marż za ryzyko, rekompensując ryzyko, na jakie byłby wystawiony pożyczkodawca niepowiązany. Warto zwrócić uwagę na malejący trend tego oprocentowania, co wynika z malejącego trendu marży za dodatkowe ryzyko, wyznaczonej na podstawie analizy oprocentowań kredytów konsumpcyjnych. Po kryzysie kredytowym z lat 2007-2010 w wielu krajach, w tym w Polsce, wprowadzano sukcesywnie restrykcje dotyczące polityki kredytowej banków, narzucające większą ostrożność w udzielaniu kredytów, co ma na celu redukcję ponoszonego przez banki ryzyka. Zbadanie stopnia, w jakim malejący trend marż wynika z regulacyjnego ograniczania ryzyka jest ciekawym kierunkiem badań rozszerzających tematykę zaprezentowaną w niniejszej pracy. 


\section{Wnioski}

Przeciwdziałanie wykorzystaniu cen transferowych do optymalizacji podatkowej jest istotną kwestią poruszaną na forum zarówno międzynarodowym, jak i krajowym. Jednym z rodzajów transakcji zawieranych przez podmioty powiązane są pożyczki. Sposób wyceniania pożyczek na potrzeby cen transferowych nie jest jednoznacznie przedstawiany w literaturze, ponieważ zależy on od wielu różnych czynników.

Bardzo ważnym elementem, który należy uwzględnić, ustalając rynkowy poziom cen pożyczek, jest ryzyko. W artykule zweryfikowano hipotezę dotyczącą uwzględniania ryzyka przy ustalaniu cen pożyczek między podmiotami powiązanymi. Przeprowadzone badania empiryczne nie dają podstaw do jej odrzucenia, wobec czego konkludujemy, że stopień ryzyka ponoszonego przez pożyczkodawcę jest istotnym czynnikiem wpływającym na cenę udzielanej pożyczki i powinien być uwzględniany przy ustalaniu ceny transferowej w przypadku pożyczek między podmiotami powiązanymi.

Przeprowadzając badanie stwierdzono, że dostęp do danych, które byłyby idealnie porównywalne $\mathrm{z}$ danymi dotyczącymi pożyczek zawieranych przez osoby fizyczne z powiązaną spółką, jest bardzo utrudniony, dlatego pomocne jest korzystanie z informacji z sektora bankowego. Badanie pokazało, że występują kredyty o różnym poziomie zabezpieczenia i ma ono wpływ na cenę kredytu. Wysokość wyznaczonych w badaniu marż dla poszczególnych kredytów zależała przede wszystkim od stopnia zabezpieczenia, czyli ryzyka.

Na podstawie przeprowadzonego badania autorzy formułują następujące zalecenia dotyczące właściwego podejścia do sporządzenia dokumentacji cen transferowych w przypadku transakcji pożyczek między podmiotami powiązanymi:

- uwzględnienie wszystkich okoliczności pożyczki; niepoprzestawanie jedynie na bezrefleksyjnym wykorzystaniu stawek oprocentowania z dostępnych zbiorów danych;

- określenie stopnia ryzyka ponoszonego przez strony transakcji (zwłaszcza pożyczkodawcę) i odniesienie go do ryzyka charakteryzującego transakcje rynkowe będące bazą porównawczą;

- wyznaczenie RRSO i obliczenie, zgodnie z przedstawioną w artykule metodą, wysokości marż rzeczywistych, będących - w zestawieniu ze stopniem ryzyka - właściwym parametrem oceny rynkowości analizowanych transakcji.

Należy uwzględnić fakt, że badanie dotyczyło kredytów o wartości od 50 tys. zł do $5 \mathrm{mln}$ zł i okresów od 8 miesięcy do 5 lat, warto byłoby więc przeprowadzić badania dotyczące również kredytów o większej wartości i innych terminach spłaty. 
Uwzględnienie statystyk NBP, dających wnioski zbieżne z płynącymi z analizy konkretnych kredytów dwóch rzeczywistych spółek, pozwala na formułowanie pewnych uogólnień, oczywiście z odpowiednią dozą ostrożności i postulatem potwierdzenia ich przez kolejne badania.

\section{Bibliografia}

Baćkowski D. (2001), Ceny transferowe w spótkach córkach międzynarodowych koncernów działających w Polsce - prezentacja wyników badań, „Zeszyty Teoretyczne Rachunkowości”, 2.

Dmowski A. (2006), Ceny transferowe. Analiza regulacji prawnych. Przyktady dokumentacji podatkowej. Warszawa: Difin.

EU (2005), Communication from the Commission to the Council, the European Parliament And The European Economic And Social Committee on the work of the EU Joint Transfer Pricing Forum on transfer pricing documentation for associated enterprises in the EU, https://eur-lex.europa.eu/legalcontent/EN/TXT/?uri=COM\%3A2005\%3A0543\%3AFIN (data dostępu: 19.09.2018).

Felis P. (2008), Ryzyko podatkowe podmiotów powiąanych w konstrukcji podatków dochodowych, „Studia i Prace Kolegium Zarządzania i Finansów”, 90.

Gajewski D.J. (red.) (2019), Ceny transferowe. Wybrane zagadnienia, Lex, wyd. el. Georgijew-Ciastoń I., Sadowski R. (2003), Ceny transferowe - ustalanie dochodu zakładu zagranicznego przedsiębiorstwa, „Monitor Podatkowy”, 2.

Górski M.J., Zbroiński A. (2016), Ceny transferowe. Protokót kontroli, Lex, wyd. el.

Jaeger H. (1987), Die Bewertung von konzerninternen Lieferungen und Leistungen in der operativen Planung. Heidelberg: Phisica Verlag.

Jankowski J. (2019), Optymalizacja podatkowa w podatkach dochodowych - dopuszczalność i prawne granice. Warszawa: C.H. Beck.

Kaniewska-Środecka M. (2018), Zarządzanie ryzykiem cen transferowych. Warszawa: C.H. Beck.

Klimek K. (2019), Jak ustalić rynkowe oprocentowanie pożyczek pomiędzy podmiotami powiazanymi dla potrzeb cen transferowych, odpowiedź QA 1359845, Lex, wyd. el.

Kolanowski T., Winiarski K. (2018), Co moga sady administracyjne $w$ aspekcie cen transferowych?, „Przegląd Podatkowy”, 12.

Kosieradzki T., Piekarz R., Rynkowska A. (2019), Ceny transferowe 2019. Mechanizmy, dokumentacje, raportowanie, Lex, wyd. el.

Krzyżaniak A., Hornowska A. (2020), Kiedy korzystać z przepisów dotyczacych safe harbour, „Rzeczpospolita”, 20.01.2020. 
Laskowska M. (2019), Zmiany w polskich regulacjach dotyczacych cen transferowych, „Przegląd Podatkowy”, 1.

Mariański A., Wiśniewski K,. Kaczmarek P., Kalicińska A., Majcherczak J., Michalak A. (2017), Dokumentacja cen transferowych za rok 2017. Warszawa: Gremi Media SA.

Menet G. (2011), Oprocentowanie pożyczki wewnatrzkorporacyjnej jako cena transferowa, „Nauki o finansach”, 7.

Mika J. (2017), Ceny transferowe. Komentarz do rozporzadzenia. Metody ustalania i szacowania cen transferowych. Analiza porównywalności. Warszawa: C.H. Beck.

NBP (2015), Kredyt bankowy jako źródło finansowania działalności. Materiat opracowany przez NBP w ramach projektu „Przedsiębiorczość w praktyce”, Rzeszów.

NBP, statystyka stóp procentowych, http://www.nbp.pl/home.aspx?f=/statystyka/ pieniezna_i_bankowa/oprocentowanie.html (data dostępu: 19.09.2018).

Nykiel W., Strzelec D. (red.) (2014), Podmioty powiazane, Lex, wyd. el.

OECD (2017), OECD Transfer Pricing Guidelines for Multinational Enterprises and Tax Administrations 2017. Paris: OECD Publishing, http://dx.doi. org/10.1787/tpg-2017-en.

OECD (2020), Transfer Pricing Guidance on Financial Transactions: Inclusive Framework on BEPS Actions 4, 8-10. Paris: OECD, http://www.oecd.org/ tax/beps/transfer-pricing-guidance-on-financial-transactions-inclusive-framework-on-beps-actions-4-8-10.htm

O’Shaughnessy M. (2003), Ceny transferowe. Warszawa: C.H. Beck.

Piekarz R. (red.) (2018), Przewodnik po dokumentacji cen transferowych. Nowe zasady od 2018 roku. Przyktady dokumentacji krok po kroku, Wolters Kluwer, Lex, wyd. el.

Rozporządzenie Ministra Finansów z dnia 10 października 1997 r. w sprawie sposobu i trybu określania dochodów podatników w drodze oszacowania cen w transakcjach dokonywanych przez tych podatników, Dz.U. z 1997 r., nr 128 , poz. 833 ze zm.

Rozporządzenie Ministra Finansów (2009a) z dnia 10 września 2009 r. w sprawie sposobu i trybu określania dochodów osób fizycznych w drodze oszacowania oraz sposobu i trybu eliminowania podwójnego opodatkowania osób fizycznych w przypadku korekty zysków podmiotów powiązanych, Dz.U. z 2009 r., nr 160, poz. 1267 ze zm.

Rozporządzenie Ministra Finansów (2009b) z dnia 10 września 2009 r. w sprawie sposobu i trybu określania dochodów osób prawnych w drodze oszacowania oraz sposobu i trybu eliminowania podwójnego opodatkowania osób prawnych w przypadku korekty zysków podmiotów powiązanych, Dz.U. z 2009 r., nr 160, poz. 1268 ze zm. 
Rozporządzenie Ministra Finansów z dnia 21 grudnia 2018 r. w sprawie cen transferowych w zakresie podatku dochodowego od osób prawnych, Dz.U. z 2018 r., poz. 2491 ze zm.

Rozporządzenie Ministra Finansów z dnia 21 grudnia 2018 r. w sprawie cen transferowych w zakresie podatku dochodowego od osób fizycznych, Dz.U. z 2018 r., poz. 2502 ze zm.

Stamblewska-Urbaniak E., Zbroiński A. (2019), Znaczenie rezultatów działań 8-10 w ramach Projektu BEPS dla podatników realizujących transakcje z podmiotami powiazanymi, „Przegląd Podatkowy”, 9.

Sulik-Górecka A. (2009), Wycena i dokumentacja transakcji między podmiotami powiązanymi $w$ świetle obowiązujacych przepisów, „Zeszyty Teoretyczne Rachunkowości”, 53.

Ścierska E. (red.) (2016), Ceny transferowe. Lokalna i grupowa dokumentacja podatkowa oraz inne obowiązi sprawozdawcze, Lex, wyd. el.

Ustawa z dnia 26 lipca 1991 r. o podatku dochodowym od osób fizycznych, Dz.U. z 2019 r., nr 1387 ze zm.

Ustawa z dnia 15 lutego 1992 r. o podatku dochodowym od osób prawnych, Dz.U. z 2019 r., nr 865 ze zm.

Ustawa z dnia 12 maja 2011 r. o kredycie konsumenckim, Dz.U. z 2011 r., nr 126, poz. $715 \mathrm{ze}$ zm.

Wiśniewski P., Kromer W. (2015), Ceny transferowe. Warszawa: Difin.

Wyciślok J. (2014), Ceny transferowe. Przedsiębiorstwa powiązane. Przerzucanie dochodów. Warszawa: C.H. Beck.

\section{Streszczenie}

Jednym z instrumentów, jakie mogą wykorzystywać podmioty gospodarcze do obniżania ciężarów podatkowych, są ceny transferowe, stosowane zarówno w obrocie międzynarodowym, jak i w transakcjach w obrębie jednego kraju. Mogą one wystąpić nie tylko przy transakcjach sprzedaży, lecz również udzielania pożyczek. Celem artykułu jest ocena wpływu stopnia ryzyka ponoszonego przez pożyczkodawcę na cenę udzielanej pożyczki przy ustalaniu ceny transferowej w przypadku transakcji pożyczki między podmiotami powiązanymi. W artykule postawiono następującą hipotezę: stopień ryzyka ponoszonego przez pożyczkodawcę jest istotnym czynnikiem wpływającym na cenę udzielanej pożyczki i powinien być uwzględniany przy szacowaniu ceny transferowej w przypadku pożyczek między podmiotami powiązanymi. W części teoretycznej zastosowane metody naukowe to krytyczny przegląd literatury, analiza krajowych aktów prawnych oraz wytycznych OECD. W części empirycznej przedstawiono wyznaczanie rynkowego 
poziomu cen pożyczek, bazując na zbiorze rzeczywiście udzielonych kredytów oraz danych statystycznych Narodowego Banku Polskiego, co było przedmiotem przygotowanej przez autorów dokumentacji cen transferowych. Badanie nie dało podstaw do odrzucenia hipotezy, wobec czego sformułowano wniosek, że stopień ryzyka ponoszonego przez pożyczkodawcę jest istotnym czynnikiem wpływającym na cenę udzielanej pożyczki i powinien być uwzględniany przy wyznaczaniu ceny transferowej w przypadku pożyczek między podmiotami powiązanymi. Badanie pokazało, że ustalanie rynkowego poziomu cen pożyczek przez samo porównanie ich z cenami innego finansowania dłużnego, bez uwzględnienia ryzyka, jest niewystarczające. Ten aspekt, wzbogacony empiryczną analizą wpływu ryzyka na ceny kapitału dłużnego, oraz sformułowanie zaleceń dotyczących właściwego sporządzania dokumentacji cen transferowych w przypadku transakcji pożyczek, to oryginalny wkład autorów.

Slowa kluczowe: podatki dochodowe, ceny transferowe, pożyczki, koszt kapitału dłużnego, ryzyko

\section{Summary}

\section{The impact of the risk degree on the level of transfer prices for loans} between related entities

Transfer pricing is one of the instruments that business entities can use to reduce tax burdens, and they are being used both in international trade and in transactions within one country. They can occur not only in sales transactions, but also in granting loans. The purpose of the article is to assess the impact of the degree of risk borne by the lender on the price of the loan granted when determining the transfer price in the case of loans between related entities. The following hypothesis was examined: the degree of risk borne by the lender is a significant factor that affects the price of the loan granted and should be taken into account when determining the transfer price of loans between related entities. In the theoretical part, the scientific methods used are a critical literature review and an analysis of national legal acts and OECD guidelines. The empirical part presents the determination of the market level of loan prices based on a set of actually granted bank loans and statistical data of the National Bank of Poland, which was the subject of the transfer pricing documentation prepared by the authors. The study did not provide grounds to reject the hypothesis, so it was concluded that the degree of risk borne by the lender is an important factor that affects the price of the loan granted and should be taken into account when determining the transfer price of loans between related entities. The study showed 
that determining the market level of loan prices by simply comparing them with the prices of other debt financing, without taking into account the risk, is insufficient. This aspect, enriched with an empirical analysis of the impact of risk on debt capital prices, and the formulation of recommendations for the proper preparation of transfer pricing documentation for loan transactions, is the original contribution of the authors.

Keywords: income taxes, transfer pricing, loans, cost of debt, risk 